\title{
Student Learning Outcomes using the Snow Cube Throwing Learning Model with Cooperative Settings
}

\author{
Nenden Mutiara Sari ${ }^{1 *}$, Hanhan Subhan Munawar ${ }^{2}$ \\ ${ }^{1}$ Program Studi Magister Pendidikan Matematika, Universitas Pasundan, Jl. Sumatera No. \\ 41, Bandung, Jawa Barat, Indonesia \\ ${ }^{2}$ SMAN 1 Cikalongwetan, Jl. Raya Cikalongwetan No. 153, Bandung Barat, Jawa Barat, \\ Indonesia
}

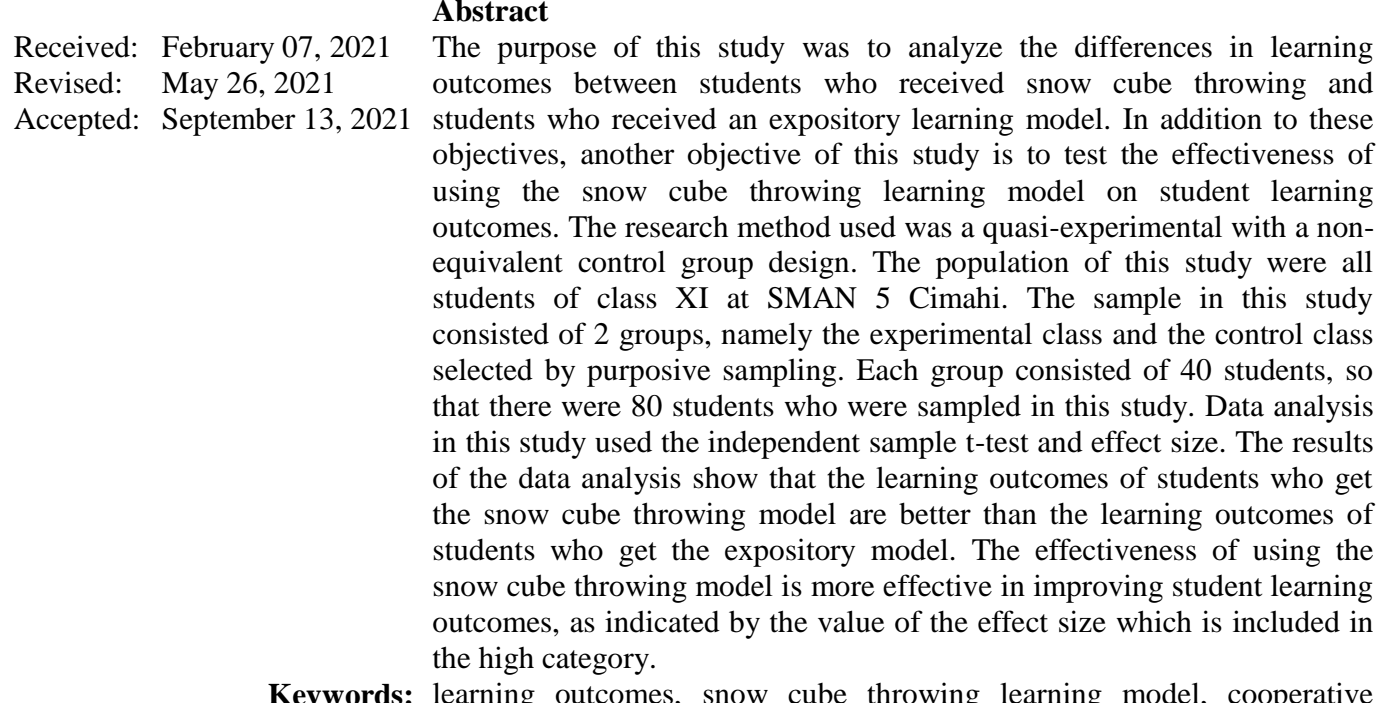

Keywords: learning outcomes, snow cube throwing learning model, cooperative
learning

(*) Corresponding Author: nenden.mutiara@unpas.ac.id, 085222366633

How to Cite: Sari, N.M. \& Munawar, H.S. (2021). Student learning outcomes using the snow cube throwing learning model with cooperative settings. Formatif: Jurnal Ilmiah Pendidikan MIPA, 11 (2): 173182. http://dx.doi.org/10.30998/formatif.v11i2.8715

\section{INTRODUCTION}

Learning outcomes are defined as statements about what students know and understand after completing the learning process (Harris \& Clayton, 2019). More specifically, Komariyah \& Laili (2018) state that learning outcomes are the result of an activity that has been done, created, obtained by hard work, both individually and in groups after experiencing the learning process. Based on these two definitions, mathematics learning outcomes can be interpreted as the abilities students have in mathematics lessons obtained from experiences and exercises during the learning process. The description of mathematics learning outcomes is reflected in the teacher's complaint stating that the scores of the daily math tests of most students were still below the minimum completeness criteria. In addition, the description of mathematics learning outcomes can also be seen from the lower National Examination results compared to other subjects from year to year at the Secondary School level (Kemdikbud, 2019). The evaluation of students' mathematics ability assessment at the international level can be 
seen from the PISA results. The results of the Program for International Student Assessment (PISA) for Indonesia in 2018 have been announced by The Organization for Economic Co-operation and Development (OECD). Since the first time Indonesia took the PISA test in 2003, the average PISA score until 2018 was 377.This score is still very far from the mathematics scores obtained by China and Singapore, which scored 591 and 569 (OECD, 2018)

Mathematics is one of the most difficult and tedious subjects for most students. Most students consider mathematics to be a difficult thing because it requires good reasoning skills, the ability to analyze and memorize several formulas. In addition, the results of Acharya's (2017) study state that one of the factors affecting students' difficulties in learning mathematics is due to the lack of students practicing solving math problems. To do well in mathematics, students must have extra time to practice. In general, mathematics achievement is determined by how much effort students put in practicing. In this case, Thapa in (Acharya, 2017) argues that students should be prepared for extra practice for better performance in mathematics.

In fact, students can only practice working on a few questions in one class lesson. Even so, students do not give more time to study mathematics at home. Therefore, it is necessary to maximize the practice of doing questions in school. One effort that can be done is to choose the right teaching method. In teaching and learning activities, the method plays a role that is no less important than other components in teaching and learning activities. Teaching effectively relies heavily on choosing methods that are compatible with the goals of teaching (Bawa, 2021).

The drill method is a method used to provide repeated skills training to achieve dexterity or skills in doing something, where the teacher provides this exercise to students in groups or individually (Ratnaningsih, 2012). The drill method is usually used in practicing numeracy skills, suitable for application in mathematics learning such as calculating multiplication, addition, division, and other types of calculations, which do not require complicated procedures. Even so, students' numeracy skills will greatly support mastery of mathematics material. Through this exercise, students will be increasingly skilled at solving math problems. The drill and repetition methods have improved student learning outcomes and have had a positive impact on student motivation. (Wahyuni, Rahman \& Ilyas, 2017; Dewi, Trisnawati \& Kristina, 2020; Bawa, 2021).

The presentation of this drill method cannot be done only by giving a lot of questions without being supported by the right learning model and learning strategy. The learning model that is considered suitable for student learning activities through the drill method is the snow cube throwing learning model. The snow cube throwing learning model is a learning model developed from the snowball throwing learning model. The purpose of developing this model is so that students can practice many math problems in one lesson in a fun atmosphere. The difference between the two learning models lies in the learning media used. If the snowball throwing media model used is paper containing questions and squeezed like a ball (Agustina, 2013), however, the snow cube throwing media used is a cube made of cardboard (Sari, 2017). These math problems will be attached to the sides of the cube. The similarity of these two models lies in the activity of throwing. This activity of throwing the cube is what gives interest in learning mathematics, because through this activity, students can learn while playing. Learning activities using the snow cube throwing learning model are presented in a cooperative setting, where according to Amaliah, Syamsudduha and Qaddafi (2017) that through cooperative learning, teachers can take advantage of student activeness without having to have differences in the status of students and contain elements of play. With the element of play in learning activities, it is hoped that it will increase student interest in learning 
mathematics. As we know that interest is closely related to student outcomes. Based on this explanation, the purpose of this study was to analyze the effectiveness of learning snow cube throwing in improving student learning outcomes.

\section{METHODS}

This research is quasi-experimental research. The selection of this study was based on the consideration that the existing class had been formed beforehand and it was impossible to do purely random grouping of students. This study uses a quantitative approach with a nonequivalent control group design. The population of this study were all students of class XI at SMAN 5 Cimahi, West Java, Indonesia. The sample in this study consisted of 2 groups, namely the experimental class and the control class selected by purposive sampling. Each group consisted of 40 students, so that there were 80 students who were sampled in this study. The experimental class obtained the snow cube throwing learning model and the control class obtained the expository model. Mathematical problems presented in cubes are only given to the experimental group, while the presentation of mathematics problems in the control class is given in the HVS paper. The research instrument used 10 essay test questions on the derivative material, and the observation sheet was used to observe the application of the snow cube throwing model. Before the test instrument is used for research, it is tested for validity, reliability, distinguishing power and level of difficulty.

Based on the results of the analysis of the instruments that have been carried out, Pearson's correlation coefficient for measuring validity was $0.71 ; 0.76 ; 0.67 ; 0.47 ; 0.46$; $0.72 ; 0.55 ; 0.56 ; 0.48 ; 0.71$ with reference to the criteria of Suherman (2003), the items used in this study were valid items. The reliability coefficient obtained is 0.78 so that this instrument has high reliability (Ruseffendi, 2005). The index of distinguishing power and its interpretation which refers to Suherman (2003) owned by this instrument are respectively 0.48 (good); 0.65 (good); 0.59 (good); 0.42 (good); 0.41 (good); 0.50 (good); 0.37 (sufficient); 0.42 (good); 0.28 (sufficient); 0.53 (good), based on these results corrected sentences in questions number 7 and 9. This instrument has an index of the level of difficulty and its interpretation refers to Suherman (2003), respectively 0.78 (easy); 0.45 (medium); 0.53 (medium); 0.69 (medium); 0.74 (easy); 0.29 (difficult); 0.76 (easy); 0.49 (medium); 0.81 (easy); 0.60 (medium).

The data analysis technique used in this research is descriptive statistics, the Kolmogorov-Smirnov normality test, the Levene homogeneity test, the t-test to test the similarities and differences in the mean, the effect size test to test the effectiveness of the snow cube throwing learning model. The effect size can be calculated by formulation (Cohen, 1998) and described in more detail by (Hake, 2002). The criteria for the size of the effect size can be seen in Table 1 .

Table 1. Effect size criteria

\begin{tabular}{cc}
\hline Effect Size & Category \\
\hline $\mathrm{d}<0,2$ & small \\
$0,2<\mathrm{d}<0,8$ & medium \\
$\mathrm{d}>0,8$ & high \\
\hline
\end{tabular}

Qualitative data documentation in the form of observations was carried out to see the suitability of the implementation of learning in the classroom with the lesson plans and to see the attitudes of students during the learning process. The observations carried out were systematic and non-systematic observations. Systematic observation is an 
observation that is guided by the observation guidelines that have been prepared previously. Meanwhile, non-systematic guidelines are observations made without a prior structure or plan, so that the observer can capture what can be caught. In addition, observers can also conduct interviews with students, to strengthen or clarify the results of these observations.

\section{RESULTS \& DISCUSSION}

\section{Results}

Pretest is done to determine students' initial abilities, and posttest is used to determine changes in student learning outcomes. The data on the learning outcomes of the experimental and control class students can be seen in Table 2 .

Table 2. Pretest and Posttest Descriptive Statistics for Experiment and Control Classes

\begin{tabular}{lcccc}
\hline & \multicolumn{2}{c}{ Experiment Class } & \multicolumn{2}{c}{ Control Class } \\
\hline Data & Pretest & Posttest & Pretest & Posttest \\
\hline Max & 11 & 100 & 11 & 92 \\
Min & 5 & 66 & 5 & 45 \\
Mean & 7,88 & 82,70 & 7,78 & 66,83 \\
SD & 1,488 & 2,86 & 1,476 & 2,90 \\
\hline
\end{tabular}

It can be seen in table 2 that the pretest average of the experimental group is not much different from the average pretest of the control group, while the average post-test of the experimental group is higher than the average of the control class. However, to see the significance of the similarities and differences in the mean of the two groups, it is necessary to carry out further tests by first testing the normality and homogeneity of the data. The results of the normality and homogeneity tests of the pretest data for the two groups are shown in Table 3.

Table 3. Normality and Homogeneity Test Data pretest

\begin{tabular}{ccccc}
\hline \multirow{2}{*}{ Class } & \multicolumn{2}{c}{ Normality Test } & \multicolumn{2}{c}{ Homogeneity Test } \\
\cline { 2 - 5 } & Statistic & Sig. & $\begin{array}{c}\text { Levene } \\
\text { Statistic }\end{array}$ & Sig. \\
\hline $\begin{array}{c}\text { Experiment } \\
\text { Control }\end{array}$ & 0,947 & 0,062 & 0,000 & 0,984 \\
\hline
\end{tabular}

Table 3 shows that the normality test results of the two data groups have a sig. value. $>0.05$, so the learning outcome data for the two groups were normally distributed. The homogeneity test data in Table 3 shows that the sig. $>0.05$, meaning that the variance between groups is homogeneous. Furthermore, to determine whether the students' initial abilities between the two groups were not significantly different, it would be continued by conducting an independent sample t-test, with a significance level of $5 \%$. The results of the pretest mean similarity test using the t-test showed that the sig. 2 tailed is 0.764 . Hence, the sig. $>0.05$, it can be concluded that the students 'initial abilities before learning snow cube throwing were not significantly different from the students' initial abilities before receiving expository learning. Furthermore, to see the significance of the difference in the mean post-test between the two groups, it is necessary to carry out further tests by first doing the normality and homogeneity test of the posttest data. 
Table 4. Normality and Homogeneity Test Data Posttest

\begin{tabular}{|c|c|c|c|c|}
\hline \multirow{2}{*}{ Class } & \multicolumn{2}{|c|}{ Normality Test } & \multicolumn{2}{|c|}{ Homogeneity Test } \\
\hline & Statistic & Sig. & Levene Statistic & Sig. \\
\hline Experiment & 0,979 & 0,644 & 0,048 & 0,827 \\
\hline Control & 0,954 & 0,104 & 0,048 & \\
\hline
\end{tabular}

The results of the normality test in table 4 show that the learning outcomes data for the experimental and control classes have a sig value. $>0.05$, so the learning outcome data for the two groups were normally distributed. The homogeneity test data in Table 4 shows that the sig. $>0.05$, meaning that the variance between groups is homogeneous. Furthermore, to determine the difference in the mean between the two groups, it will be continued by conducting an independent sample t-test, with a significance level of $5 \%$. The results of the difference test between the two post-test means using the t-test showed that the sig. 2 tailed is 0.000 . Hence, the sig. $<0.05$, it can be concluded that there are significant differences in learning outcomes between students who receive snow cube throwing and students who receive expository learning. Referring to the descriptive statistics in Table 2, the average experimental class was higher than the control class average. This means that the learning outcomes of students who get the snow cube throwing learning model are better than those who get the expository model. Furthermore, to measure the effectiveness of the snow cube throwing model on student learning outcomes the effect size formula is used. Following are the results of the effect size analysis:

Table 5. Effect Size Result

\begin{tabular}{cccc}
\hline Class & Mean Gain & SD & Effect Size \\
\hline Experiment & 74,82 & 8,84 & 1,75 \\
Control & 59,05 & 9,22 & \\
\hline
\end{tabular}

Table 5 shows that the effect size is 1.75 , this shows that the effectiveness of using the snow cube throwing model is more effective in improving student learning outcomes, as indicated by the value of the effect size which is included in the high category.

\section{Discussion}

Based on the research results that have been discussed previously, student learning outcomes in the experimental class are better than the control class. So, it appears that the snow cube throwing model has a positive impact on improving student learning outcomes. This is supported by the results of research by Sari, et al. (2019) showed that the snow cube throwing model could improve students' mathematical problem-solving abilities. The advantages of the snow cube throwing model can also be seen from several relevant studies related to the use of the snowball throwing model. Some of the results of these studies indicate that the use of the snowball throwing model can improve student learning outcomes (Munawaroh \& Alamuddin, 2014; Alfiah \& Arigiyati, 2015; Firdaus, 2016; Simarmata, 2018). This snowball throwing learning model has some of the same characteristics as the snow cube throwing model. The similarity of these characteristics is in solving questions through throwing activities.

The snow cube throwing learning model is proven to be more effective in learning mathematics on derivative subjects. Students in the experimental class carry out the stages of learning such as: 1) forming groups of 2 students, for example a student with a classmate; 2) Each group is given one cube on each side there are practice questions regarding derivative material; 3 ) each group is asked to solve a problem on one side of 
the cube and write the names of themselves and their friends on the same side; 4) After finishing working on one question, the student raises his hand which indicates that the student has finished answering one question; 5) students must swap the cube they have with another group that also raises their hands, the activity of changing the cube is carried out by throwing; 6) This activity is carried out repeatedly until all sides of all the cubes in the class are filled; 7) After all the questions on the cube are filled, each group must hold 1 cube, and the teacher asks each group to make a report in the form of answers to the questions on the cube it has. If students and their group of friends find the wrong answer on the sides of the cube, then that student must correct the other group's answer with the correct answer.

In stages 1-3, students in this research study in groups with their classmates. Through group learning activities, students can work together in solving math problems, so there is an exchange of opinions during the discussion. When answering questions, there are some students who are not confident or doubtful about the answers, but through discussion activities, students can be more active because they can exchange opinions to build concepts of material being studied together. Through group work, there will be a desire to help other students in groups who are experiencing difficulties, thus making students enthusiastic about developing their thinking skills (Saregar, Latifah \& Sari, 2016). The number of group members in the snow cube throwing lesson consists of 2 people. The division of group members in small numbers aims to make the discussion process run more effectively. This is in line with the research of Farisi (2017) which states that teaching with a small number of groups is better than teaching with many groups.

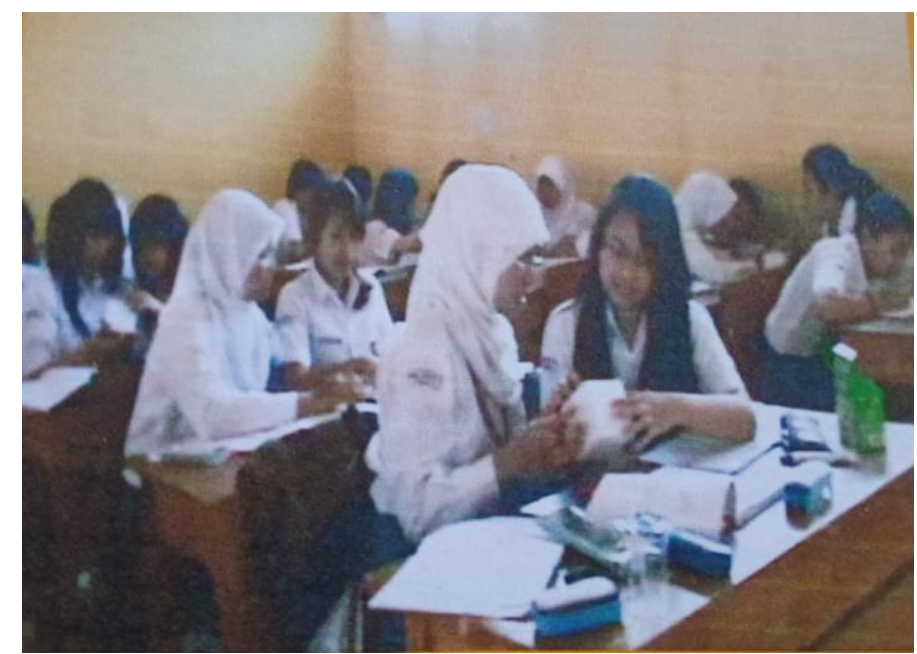

Figure 1. Students solve the problems on the side of the cube in groups

In stages 4-5, students swap the cube that has been solved with the cubes belonging to another group, by first raising their hands. Activity cube swapping is done by thrown. Based on the results of observations, students showed a sense of joy because they could learn while playing. According to Sari (2017) learning in a pleasant atmosphere will have an impact on student involvement in the classroom. Engagement is closely related to student academic achievement (Reyes et al., 2012; Dharmayana, Kumara, \& Wirawan, 2012). Student involvement in learning will make students spend all their abilities to understand the lessons given, so that student achievement in learning mathematics will increase. 


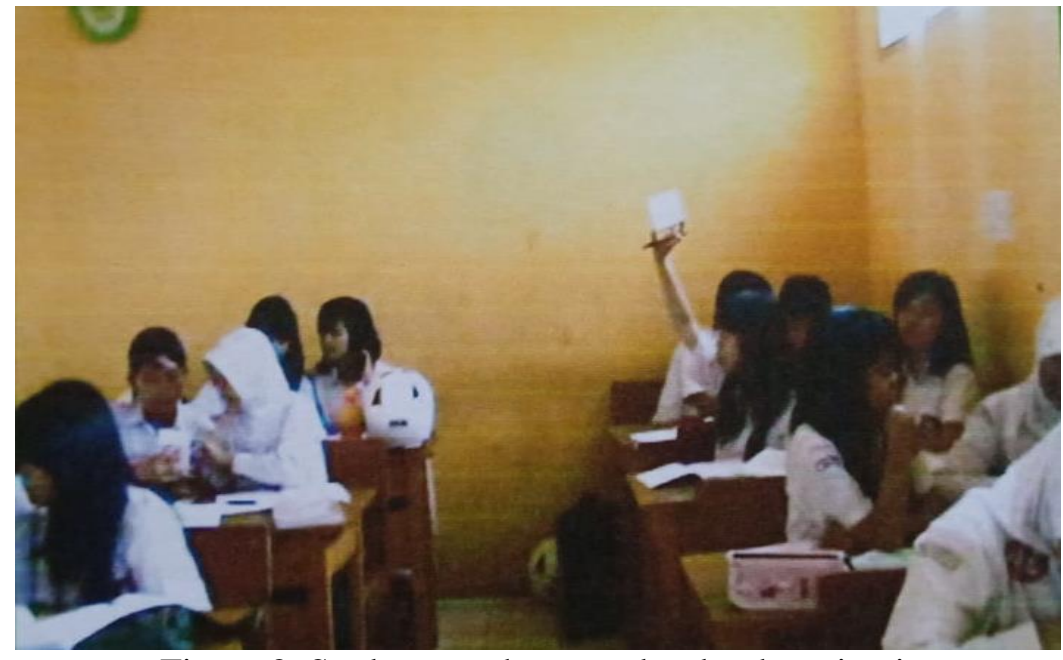

Figure 2. Students exchange cubes by throwing it

In stage 6, students work on the entire contents of the cube, by following steps 15 students solve the questions until all sides of the cube in the class are filled up. Because one class consists of 40 students, it takes 20 cubes during the learning activities. One cube consists of 6 essay questions which have difficulty levels from easy to difficult. If we add it up, the number of questions in one lesson can reach 120 questions. Practice working on a lot of questions (drill) will help students be skilled in doing questions (Lehtinen, et al., 2017). In addition, the drill and repetition methods have improved student learning outcomes and have a positive impact on student motivation. (Wahyuni, Rahman \& Ilyas, 2017; Dewi, Trisnawati \& Kristina, 2020; Bawa, 2021).

Even though the number of questions that were done in one lesson was quite large, most of the students did not realize it, because 120 questions were done by 20 groups. The results of the Sari (2017) shows that the model SCT is more effective in terms of the time needed to solve the problems of exploration.

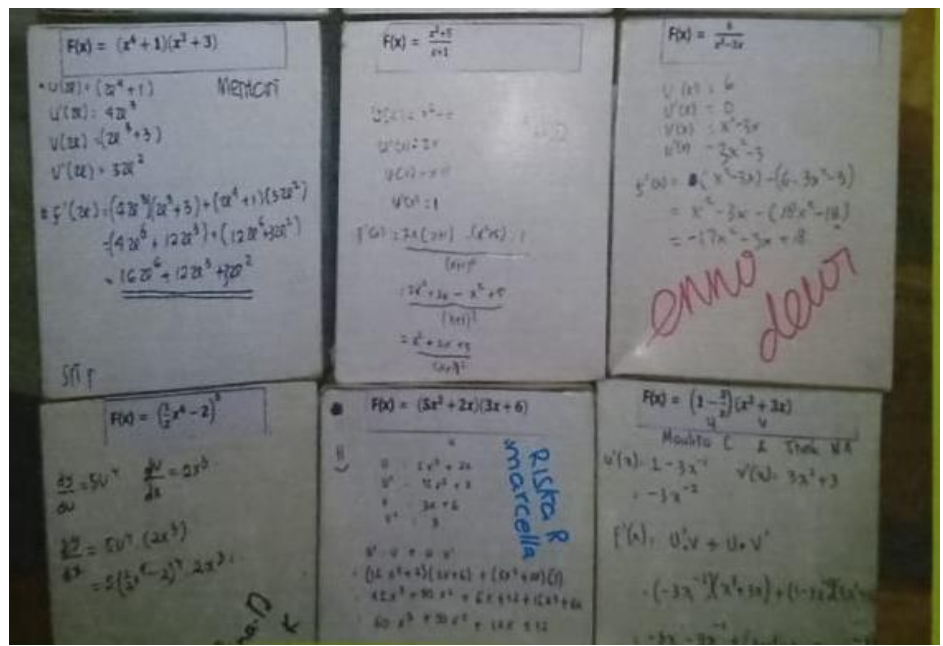

Figure 3. Examples of the cubes that have been filled by students.

In stage 7, students must make a report consisting of questions and answers contained in the cube they have. If students and their group of friends find the wrong answer on the sides of the cube, then that student must correct the other group's answer 
with the correct answer. At this stage, students who answered correctly and were able to correct other groups' answers would get points. The group that gets the most points will get a reward from the teacher. This factor will have an impact on student involvement in learning. Usually, with the reward students will study harder than usual because they don't want their group to lose to other groups. Soenarno (2019) mention the giving award in teaching can motivate and increase students' spirit to learn.

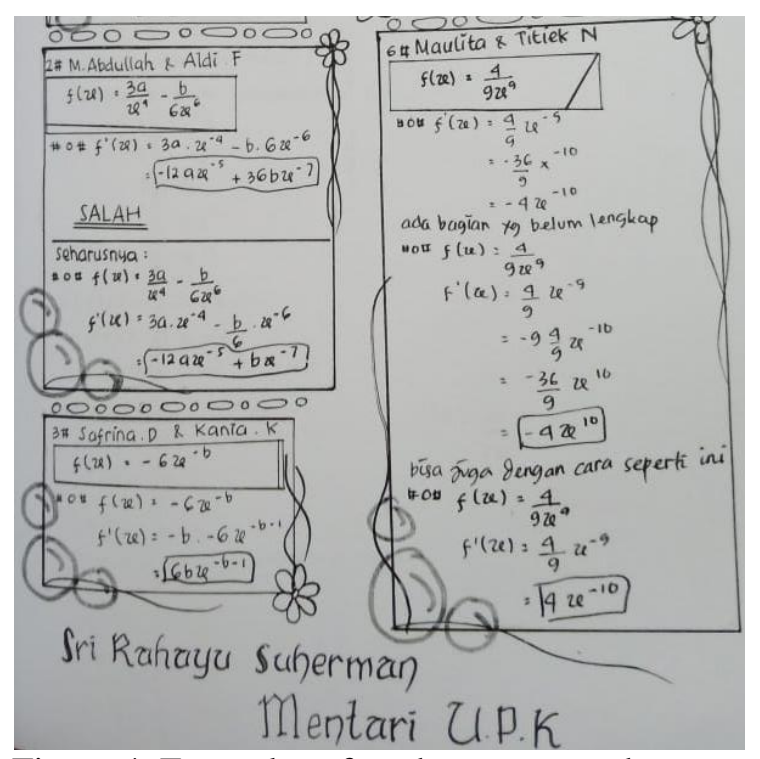

Figure 4. Examples of student-generated reports

In the report, it is seen that students learn to correct their friends' answers, this has an impact on improving learning outcomes. Based on the revised bloom taxonomy, there are 6 cognitive domains, namely: remembering, understanding, applying, analyzing, evaluating, and creating (Anderson, L.W. \& Krathwohl, 2010). Remembering, understanding, and implementing is low-level thinking whereas, high order thinking includes analyzing, evaluating, and creating. The ability of students to evaluate the results of students' answers will help students improve their high order thinking skills in mathematics lessons.

\section{CONCLUSION}

Based on the research that has been done, the conclusion of this study, as follows: (1) The learning outcomes of students who use the snow cube throwing learning model are better than the learning outcomes of students who get the expository learning model (2) The use of the snow cube learning model throwing is more effective in improving student learning outcomes. The effectiveness of using the snow cube throwing learning model is in the high category. The results of this study reinforce some previous research that to obtain very good results in studying mathematics, the students have to practice doing math problems. Fun learning activities also provide an influence on student engagement in learning activities, so this resulted in increased student learning outcomes. 


\section{REFERENCES}

Acharya, B. R. (2017). Factors affecting difficulties in learning mathematics by mathematics learners. International Journal of Elementary Education, 6(2): 8-15. https://doi.org/10.11648/j.ijeedu.20170602.11

Agustina, E. T. (2013). Implementasi model pembelajaran snowball throwing untuk meningkatkan hasil belajar siswa dalam membuat produk kria kayu dengan peralatan manual. Invotec, 9(1): 17-28. https://doi.org/10.17509/invotec.v9i1.4881

Alfiah, Y., \& Arigiyati, T. A. (2015). Efektivitas model pembelajaran snowball throwing melalui pemanfaatan prized chart terhadap hasil belajar matematika siswa kelas VII SMPN 11 Yogyakarta. Jurnal Pendidikan Matematika Union, 2(3). Retrieved from journal.ustjogja.ac.id

Amaliah, Q., Syamsudduha, S., \& Qaddafi, M. (2017). Perbandingan model pembelajaran kooperatif tipe tgt dalam permainan finding answer with barricade dan model pembelajaran kooperatif tipe stad terhadap hasil belajar fisika siswa kelas IX MTSN Gowa. Jurnal Pendidikan Fisika, 5(1). https://doi.org/https://doi.org/10.24252/jpf.v5i1.2989

Anderson, L.W. \& Krathwohl, D. R. (2010). Kerangka Landasan Untuk Pembelajaran, Pengajaran, dan Asesmen (Translation of Agung Prihantoro). New York: Addition Wesley Longman.

Bawa, I. (2021). Application of drill and recitation methods as efforts improving mathematics learning outcomes of volume cubes and blocks for class $\mathrm{V}$ students of SDN 1 Terusan Makmur 2017/2018 academic year. Jurnal Pendidikan, 21(2): 7791. https://doi.org/10.37304/jpn.v21i2.2032.

Cohen, J. (1988). Statistical Power Analysis For The Behavioral Sciences. Second Edition. Hillsdale. NJ: Lawrence Erlbaum Associates, Publishers.

Dewi, N. A. K., Trisnawati, T., \& Kristina, M. (2020). The drill method with realistic approach to improve learning outcomes of descriptive statistics in higher education. Jurnal Inovasi Pembelajaran, 6(2): 215-226. https://doi.org/10.22219/jinop.v6i2.13010

Dharmayana, I. W., Kumara, A., \& Wirawan, Y. G. (2012). Keterlibatan siswa (student engagement) sebagai mediator kompetensi emosi dan prestasi akademik. Jurnal Psikologi, 39(2012): 76-94. https://doi.org/10.22146/jpsi.6968

Farisi, S.A. (2017). Anggota kelompok belajar sebagai penentu dalam hasil belajar matematika siswa. Jurnal Ilmu Pendidikan STKIP Kusuma Negara, 8(2): 145-154. Retrieved from http://jurnal.stkipkusumanegara.ac.id/index.php/jip/article/view/180

Firdaus, A. M. (2016). Efektivitas pembelajaran matematika melalui penerapan model pembelajaran kooperatif tipe snowball throwing. Beta: Jurnal Tadris Matematika, 9(1): 61-74. https://doi.org/10.20414/Betajtm.V9i1.1

Hake, R. R. (2002). Relationship of individual student normalized learning gains in mechanics with gender, high-school physics, and pretest scores on mathematics and spatial visualization. In Physics Education Research Conference, 8(1): 1-14. Retrieved from http://www. physics. indiana. edu/ hake.

Harris, R., \& Clayton, B. (2019). The current emphasis on learning outcomes. International Journal of Training Research, 17(2): 93-97. https://doi.org/10.1080/14480220.2019.1644777

Komariyah, S., \& Laili, A. F. N. (2018). Pengaruh kemampuan berpikir kritis terhadap hasil belajar matematika. Jurnal Penelitian Pendidikan dan Pengajaran Matematika, 4(2): 55-60. https://doi.org/10.37058/jp3m.v4i2.523 
Kemdikbud. (2019). Laporan Hasil Ujian Nasional. Retrieved from https://pusmenjar.kemdikbud.go.id/hasil-un/.

Lehtinen, E., Hannula-Sormunen, M., McMullen, J., \& Gruber, H. (2017). Cultivating mathematical skills: From drill-and-practice to deliberate practice. ZDM Mathematics Education, 49(4): 625-636. https://doi.org/10.1007/s11858-017-08566

Munawaroh, M., \& Alamuddin, A. (2014). Pengaruh penerapan model pembelajaran snowball Throwing terhadap hasil belajar matematika siswa dengan pokok bahasan relasi dan fungsi. EduMa, 3(2): 163-173. Retrieved from https://www.syekhnurjati.ac.id/jurnal/index.php/eduma/article/view/62

OECD. (2018). Programme for International Student Assessment (PISA) Result From PISA 2018. Retrieved from https://www.oecd.org/pisa/publications/PISA2018_CN_IDN.pdf

Ratnaningsih, E. (2012). Efektivitas metode drill dan resitasi dalam meningkatkan pemahaman dan ketrampilan siswa terhadap hukum bacaan qolqolah dan ro'di SMP Negeri 1 Subang. Jurnal Pendidikan Agama Islam Ta'lim, 10(1): 79-94. Retrieved from http://jurnal.upi.edu/taklim/view/2264/.

Reyes, M. R., Brackett, M. A., Rivers, S. E., White, M., \& Salovey, P. (2012). Classroom emotional climate, student engagement, and academic achievement. Journal of Educational Psychology, 104(3), 700-712. https://doi.org/10.1037/a0027268

Ruseffendi, E.T. (2005). Dasar-Dasar Penelitian Pendidikan dan Bidang Non Eksakta Lainnya. Bandung: Tarsito.

Sari, N. M., Yaniawati, P., Darhim, \& Kartasasmita, B. G. (2019). The effect of different ways in presenting teaching materials on students' mathematical problem solving abilities. International Journal of Instruction, 12(4): 495-512. https://doi.org/10.29333/iji.2019.12432a

Sari, N. M. (2017). The effectiveness of snow cube throwing learning model based on exploration. In AIP Conference Proceedings, 1868(1): 050016. AIP Publishing LLC. https://doi.org/10.1063/1.4995143

Saregar, A., Latifah, S., \& Sari, M. (2016). Efektivitas model pembelajaran cups: dampak terhadap kemampuan berpikir tingkat tinggi peserta didik Madrasah Aliyah Mathla'Ul Anwar Gisting Lampung. Jurnal Ilmiah Pendidikan Fisika AlBiruni, 5(2), 233-244. https://doi.org/10.24042/jpifalbiruni.v5i2.123

Soenarno, S. M. (2019). Mastering of pedagogical content knowledge in students of natural sciences education. Formatif: Jurnal Ilmiah Pendidikan MIPA, 9 (2): 101106. http://dx.doi.org/10.30998/formatif.v9i2.2813

Suherman, E. (2003). Evaluasi Pembelajaran Matematika. Bandung: UPI

Simarmata, N. N. (2018). Upaya meningkatkan hasil belajar siswa dengan menggunakan model pembelajaran Snowball Throwing. Jurnal Ilmiah Pendidikan dan Pembelajaran, 2(1): 79-86. http://dx.doi.org/10.23887/jipp.v2i1.13854

Wahyuni, N., Rahman, A., \& Ilyas, M. (2017). The effect of implementing drill method towards learning result and motivation based on initial mathematics ability. In International Conference on Natural and Social Science (ICONSS). Retrieved from https://www.journal.uncp.ac.id/index.php/iconss/article/view/499. 